\title{
Factors Associated with Increased Walleye Production in Lined Compared to Earthen-Substrate Ponds
}

\author{
Matthew J. Ward1', Brian G. Blackwell² \\ ${ }^{1}$ South Dakota Department of Game, Fish and Parks, Blue Dog State Fish Hatchery, Waubay, USA \\ ${ }^{2}$ South Dakota Department of Game, Fish and Parks, District Office, Webster, USA \\ Email: matthew.ward@state.sd.us
}

How to cite this paper: Ward, M.J. and Blackwell, B.G. (2021) Factors Associated with Increased Walleye Production in Lined Compared to Earthen-Substrate Ponds. Open Journal of Animal Sciences, 11, 50-61. https://doi.org/10.4236/ojas.2021.111005

Received: December 3, 2020

Accepted: January 25, 2021

Published: January 28, 2021

Copyright () 2021 by author(s) and Scientific Research Publishing Inc. This work is licensed under the Creative Commons Attribution International License (CC BY 4.0).

http://creativecommons.org/licenses/by/4.0/ (c) (i) Open Access

\begin{abstract}
Walleye (Sander vitreus) fingerling production can be enhanced when the pond substrate is altered from earthen soils to an exposed liner; however, few differences in water chemistry, prey densities, and food habits have been identified that could potentially explain this production difference. Lack of an explanation led to further comparison of walleye fingerling culture between substrate types during 2016. Two ponds of each type were stocked with 1- to 3-day-old walleye fry, but lined ponds received an additional 104,166 fry/ha and were stocked 1 or 2 days later than earthen ponds (May 10). Walleyes in lined ponds achieved a growth advantage on May $31(+2.5 \mathrm{~mm})$ and on June $6(+3.3 \mathrm{~mm})$, but lengths were not significantly different at harvest (June 15). Lined ponds increased walleye yield and number 1.8 -fold while not reducing individual fish size at harvest compared to earthen ponds. Walleye food habits were generally similar between pond types with a greater number of zooplankton being consumed through June 6 followed by an increase in larval chironomid consumption at harvest (June 15). After May 30, lined ponds exhibited lower dissolved oxygen and higher ammonia-nitrogen concentrations even though earthen ponds received additional $(157 \mathrm{~kg} / \mathrm{ha}$ ) alfalfa (Medicago sativa) meal fertilizer. Also, at this time $\mathrm{pH}$ declined abruptly and remained below 8.2 in lined ponds. Moreover, the enhanced production in lined ponds coincided with walleyes that exhibited an increased pelagic $\left(\delta^{13} \mathrm{C}\right)$ signature during the culture period (2\% to $3.3 \%$ more negative). Efforts to improve production in earthen-substrate ponds should focus on increasing the pelagic signature of the food web through fertilization strategies which increase ammonia-nitrogen $(\approx 0.3 \mathrm{mg} / \mathrm{L})$ and decrease dissolved oxygen $(\approx 6.5 \mathrm{mg} / \mathrm{L})$ while maintaining a pH between 8.0 and 8.2 during the second half of the rearing interval.
\end{abstract}




\section{Keywords}

Walleye, Fingerling Culture, Pond-Substrate Type

\section{Introduction}

In drainable ponds fertilized with alfalfa (Medicago sativa), walleye (Sander vitreus) fingerling production can be enhanced when the pond substrate is altered from earthen soils to an exposed ethylene propylene diene monomer liner (hereafter lined pond [1]). This increased production advantage in lined ponds has been consistent in several trials. Doubling the stocking density in lined ponds coincided with producing three times the number of walleyes that averaged an additional $5 \mathrm{~mm}$ in length compared to those reared in earthen-substrate ponds [2]. However, few differences have been observed in water chemistry, prey densities, or walleye food habits between lined and earthen ponds [1]. This lack of information has provided little direction for potentially improving walleye production in earthen ponds other than adding an expensive liner.

Walleye larvae (2- to 3-d-old) stocked into hatchery ponds initially consume zooplankton followed by a transition to benthic invertebrates regardless of pond type [3] [4] [5]. A food web with both pelagic and benthic aspects is desirable as each can contribute to increased production [6] [7] [8]. Developing a food web with these complexities can be achieved by fertilizing with alfalfa because it serves as an immediate food source for zooplankton [9], provides organic matter for benthic invertebrates [10], and releases nutrients that sustain phytoplankton which also support zooplankton production [11] [12]. Walleye growth and production differences observed between pond substrate types suggest that alfalfa promotes a superior food web to develop in lined ponds, but the mechanism responsible for this is not understood [1]. Quantifying the $\delta^{13} \mathrm{C}$ signature of the walleyes reared in both pond types will reflect energy flow from benthic and pelagic sources [13] and assist with understanding the production differences between pond substrate types.

While the decomposition of alfalfa enhances the pond prey base, it will also affect water chemistry. Reduced dissolved oxygen concentrations [5] [14] [15] and $\mathrm{pH}$ [5] combined with ammonia releases [16] are characteristic of alfalfa fertilization. Understanding how these variables change during the culture interval is not only crucial for fish survival [14] [17], but also provides insight into important biological processes (e.g., decomposition, photosynthesis) that may affect production.

Our objective is to potentially identify factors that coincide with the increased fingerling walleye production in lined ponds and provide information that can be used to improve production in earthen ponds without having to line them. Specifically, we compare fingerling walleye performance (i.e., production, size, number), $\delta^{13} \mathrm{C}$ signatures and food habits, and water chemistry variables be- 
tween lined and earthen ponds.

\section{Methods}

\subsection{Pond Culture}

Four drainable ponds ( $0.72 \mathrm{ha}$ ) located at Blue Dog State Fish Hatchery (Waubay, South Dakota, $45^{\circ} 21^{\prime} 30.89^{\prime \prime} \mathrm{N}, 97^{\circ} 19^{\prime} 03.63^{\prime \prime}$ ) were used in this study. Two ponds of each substrate type were filled with unfiltered water from Blue Dog Lake (eutrophic, [18]) and initially fertilized during May 9-11, 2016. Initial fertilization in all ponds consisted of $227 \mathrm{~kg}$ of alfalfa meal (17\% protein, Green Meadows Forage, Gayville, South Dakota, USA) and $23 \mathrm{~kg}$ of yeast (15\% protein, Dakota Yeast, LLC, Wahpeton, North Dakota, USA). After 10 days, all ponds received another $113 \mathrm{~kg}$ of alfalfa meal. No further fertilization occurred in the lined ponds while the earthen ponds received an additional $113 \mathrm{~kg}$ of alfalfa meal after 20 days. More alfalfa meal was used in earthen ponds because they tend to maintain higher dissolved oxygen concentrations than lined ponds (unpublished data from Blue Dog State Fish Hatchery). Evaporation caused water levels to decrease in all ponds over the culture period, so lake water was added as needed to keep ponds full. Lined ponds were stocked with 225,000 walleye fry on May 11 or 12, 2016, while earthen ponds were stocked with 150,000 walleye fry on May 10, 2016. Higher stocking densities were used in lined ponds to maximize number of fingerlings produced without sacrificing fish size compared to earthen ponds [2]. We enumerated 1- to 3-day-old walleye fry by volumetric displacement and a constant of 220 fry per ml.

\subsection{Water Chemistry Parameters}

Water temperature (degrees Celsius) was measured near the substrate by the drain structure of one pond of each type every hour using a deployable TidbiT v2 Temp Logger (Onset Computer Corporation, Bourne, Massachusetts, USA) from 12:00 p.m. on May 13 through 12:00 p.m. on June 13, 2016. Ammonia-nitrogen (mg/L, salicylate method, Hach DR2010 Spectrophotometer, Loveland, Colorado, USA), pH (Oakton pH 150 meter with electrode, Oakton Instruments, Vernon Hills, Illinois, USA), and dissolved oxygen (Oakton PD 450 meter with RDO probe and sensor cap, Oakton Instruments, Vernon Hills, Illinois, USA) were measured seven times at intervals of 3 to 7 days beginning on May 12 and ending on June 10, 2016 at the drain structure of each pond. Ammonia-nitrogen was determined from a 1-L water sample collected $0.15 \mathrm{~m}$ beneath the surface, while $\mathrm{pH}$ and dissolved oxygen were measured with their respective probes at a depth of $0.10 \mathrm{~m}(\mathrm{pH})$ and $1.00 \mathrm{~m}$ (dissolved oxygen). All measurements were made in the morning beginning at 9:00 a.m.

\subsection{Walleye Sampling}

From each pond, 20 walleyes were collected by seining (3.2-mm diameter mesh) on both May 31 and June 6, 2016, and 50 walleyes were collected from the catch 
basin during pond harvest (June 14-16, 2016). All of these walleyes were initially preserved in a $10 \%$ formalin solution for at least 1 hour and then measured for total length ( $\mathrm{mm}$ ) and transferred to $95 \%$ ethanol until food habits were quantified. The number of zooplankton and larval chironomids present were determined from digestive tracts of 10 walleyes per pond for each sampling date. Additional unpreserved walleyes collected on May 31 (30 per pond) and at pond harvest (10 per pond) were frozen in pond water. These walleyes were dried at $60^{\circ} \mathrm{C}$ for 72 hours and ground into a fine powder before being shipped to Coil Laboratory (Cornell University, Ithaca, New York) for $\delta^{13} \mathrm{C}$ determination.

\subsection{Pond Harvest}

A pond of each treatment was harvested on June 14 and 16, 2016. This resulted in an average rearing interval of 35 days for lined ponds and 36 days for earthen ponds. For each pond, a known number of walleyes $(\geq 150)$ was randomly removed from the catch basin and cumulatively weighed. The number of walleyes was divided by the cumulative weight to determine the number of walleyes per $\mathrm{kg}$. The total $\mathrm{kg}$ of walleyes harvested from each pond was determined by weighing nets filled with walleyes to the nearest $0.22 \mathrm{~kg}$. For each pond, the total $\mathrm{kg}$ of walleyes harvested was multiplied by the number of fish per kg to estimate the number harvested from each pond.

\subsection{Calculations and Statistics}

Mean daily temperatures were calculated for the time period of May 14 through June 12, 2016 for each pond type, but no measure of variation was used because temperature was only measured in one pond of each type. Mean daily temperatures were summed for both pond types to compare total temperature units accumulated during that timeframe. Means and standard errors were used to describe all walleye performance metrics, food habits and $\delta^{13} \mathrm{C}$ signatures, as well as the patterns in ammonia-nitrogen, dissolved oxygen, and $\mathrm{pH}$. Small sample sizes lack power to test for normality, so a one-way analysis of variance (ANOVA) was used to compare between treatments because only very skewed distributions have a marked effect on the significance level of the F-test [19]. Water chemistry data (ammonia-nitrogen, dissolved oxygen, and $\mathrm{pH})$ were compared between and within treatments. Treatment comparisons were made after data were grouped into two timeframes (before and after May $30,2016)$ to account for not sampling these variables on the same day for each treatment. Four sampling events occurred during the earlier period and three sampling events occurred during the later period for both treatments. Within treatments, water chemistry variables were compared over time across the seven sampling dates. Pairwise comparisons between dates were made using Tukey's-honestly significant difference test. Significance was set at 0.05 for all comparisons. 


\section{Results}

\subsection{Walleye Growth and Harvest Metrics}

Walleyes in lined ponds were on average $2.5 \mathrm{~mm}$ longer on May 31 (F-ratio = 289.000, $\mathrm{df}=1,2, P=0.003)$ and $3.3 \mathrm{~mm}$ longer on June $6($ F-ratio $=19.603, \mathrm{df}$ $=1,2, P=0.047$ ) than those in earthen ponds (Figure 1). At the time of harvest, walleye size was similar between pond types (F-ratio $=0.090, \mathrm{df}=1,2, P=0.793$; Figure 1), while average yield (F-ratio $=35.373, \mathrm{df}=1,2, P=0.027$ ) and number harvested $(\mathrm{F}$-ratio $=25.409, \mathrm{df}=1,2, P=0.027$ ) were significantly higher in lined ponds (Table 1). Specifically, the lined treatment produced an average increase of 78,585 walleyes and $23.1 \mathrm{~kg}$ of biomass without reducing fish size at harvest (Table 1; Figure 1).

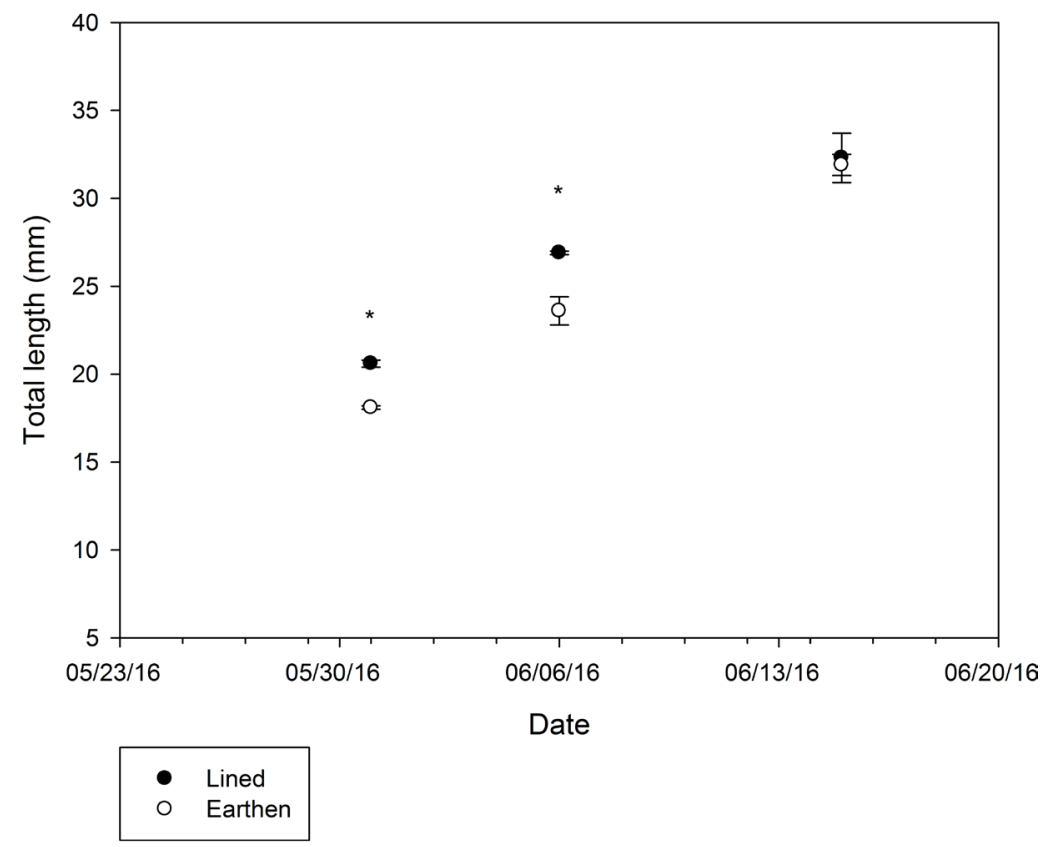

Figure 1. Mean $( \pm \mathrm{SE})$ total length of walleye reared in 0.72-ha, lined or earthen ponds (n $=2$ ) at Blue Dog State Fish Hatchery, South Dakota. Lined ponds were stocked on May 11 or 12 while earthen ponds were stocked on May 10, 2016. Harvest length data is displayed on June 15 because each treatment had one pond harvested on June 14 and 16, 2016. An asterisk represents a significant difference $(P \leq 0.05)$ between treatments.

Table 1. Mean ( \pm SE) number, yield (total $\mathrm{kg}$ ), and size (walleyes per $\mathrm{kg}$ ) of walleye harvested from two lined and two earthen ponds (0.72-ha) at Blue Dog State Fish Hatchery, South Dakota with one pond of each treatment being harvested on June 14 and 16, 2016. Walleye were reared for an average of 35 days in the lined and 36 days in the earthen treatment. Lined ponds were stocked with 225,000 fry, while earthen ponds were stocked with 150,000 fry.

\begin{tabular}{cccc}
\hline Treatment & Number Harvested & Yield (kg) & Size (walleyes/kg) \\
\hline Lined & $180,015 \pm 13,965^{\mathrm{y}}$ & $52.1 \pm 3.9^{\mathrm{y}}$ & $3498 \pm 528$ \\
Earthen & $101,430 \pm 6930^{\mathrm{z}}$ & $29.0 \pm 0.4^{\mathrm{z}}$ & $3498 \pm 198$ \\
\hline
\end{tabular}

Differing superscripts within a column indicate a significant difference between treatments $(P \leq 0.05)$. 


\subsection{Walleye Food Habits and $\delta^{13} \mathrm{C}$ Signatures}

The numbers of zooplankton and chironomids within walleye digestive tracts were not significantly different between pond types (all three comparisons; F-ratio $\leq 5.312 ; \mathrm{df}=1,2 ; P \geq 0.148$; Table 2). By number, zooplankton were more common through June 6 and chironomids were more abundant at pond harvest (Table 2). Walleye $\delta^{13} \mathrm{C}$ signatures were significantly less enriched in lined ponds on both May 31 (F-ratio $=44.901, \mathrm{df}=1,2, P=0.022$ ) and at pond harvest (F-ratio $=461.025, \mathrm{df}=1,2, P=0.002)$. Walleye $\delta^{13} \mathrm{C}$ signatures increased in both pond types over time (Table 3 ).

\subsection{Water Chemistry}

Water temperature tended to be slightly higher in the lined ponds during most of the culture period (Figure 2). The lined ponds accumulated 18 more temperature units than the earthen ponds from May 14 through June 12, 2016.

Ammonia-nitrogen concentrations began low in both treatments and were not significantly different prior to May 30 (F-ratio $=0.200, \mathrm{df}=1,14, P=0.662$; Figure 3, Table 4). After May 30, concentrations remained low in earthen ponds (F-ratio $=1.190, \mathrm{df}=6,7, P=0.407)$, but significantly increased to $0.3 \mathrm{mg} / \mathrm{L}$ in lined ponds (F-ratio $=53.367, \mathrm{df}=6,7, P<0.000$ ) before significantly decreasing on June $10(P=0.001)$. Ammonia-nitrogen concentrations were significantly higher in lined compared to earthen ponds after May 30 (F-ratio $=24.857, \mathrm{df}=$ $1,10, P=0.001)$.

No significant difference in $\mathrm{pH}$ between pond substrate types was identified before $($ F-ratio $=0.878, \mathrm{df}=1,14, P=0.762)$ or after May $30($ F-ratio $=1.558, \mathrm{df}$

Table 2. Mean ( \pm SE) number of zooplankton and larval chironomids per gastrointestinal tract of walleye reared at Blue Dog State Fish Hatchery, South Dakota, in two ponds of each substrate type during 2016. Ten walleyes were examined per pond per date. Lined ponds were stocked on May 11 or 12, while earthen ponds were stocked on May 10. No significant differences $(P>0.05)$ were detected between treatments at any sampling date.

\begin{tabular}{ccccccc}
\hline \multirow{2}{*}{ Pond type } & \multicolumn{3}{c}{ Zooplankton/Walleye } & \multicolumn{3}{c}{ Chironomids/Walleye } \\
\cline { 2 - 7 } & May 31 & June 6 & Harvest & May 31 & June 6 & Harvest \\
\hline Lined & $10.1 \pm 4.5$ & $23.4 \pm 5.8$ & $2.6 \pm 2.4$ & $1.3 \pm 0.9$ & $0.3 \pm 0.3$ & $3.4 \pm 2.8$ \\
Earthen & $11.8 \pm 1.2$ & $10.0 \pm 0.4$ & $1.4 \pm 0.4$ & $2.1 \pm 0.9$ & $2.0 \pm 0.4$ & $5.1 \pm 2.7$ \\
\hline
\end{tabular}

Table 3. Mean $\left( \pm\right.$ SE) $\delta^{13} \mathrm{C}(\%)$ signatures for walleye collected from lined and earthen ponds on May 31 and at pond harvest (June 14 or 16, 2016) at Blue Dog State Fish Hatchery, South Dakota. Lined ponds were stocked on May 11 or 12, while earthen ponds were stocked on May 10.

\begin{tabular}{ccc}
\hline Date & May $31 \delta^{13} \mathrm{C}(\%)$ & Harvest $\delta^{13} \mathrm{C}(\% 0)$ \\
\hline Lined & $-29.7 \pm 0.2^{\mathrm{y}}$ & $-27.0 \pm 0.2^{\mathrm{y}}$ \\
Earthen & $-27.7 \pm 0.2^{\mathrm{z}}$ & $-23.7 \pm 0.1^{\mathrm{z}}$ \\
\hline
\end{tabular}

Differing superscripts within a column indicate a significant difference $(P \leq 0.05)$. 


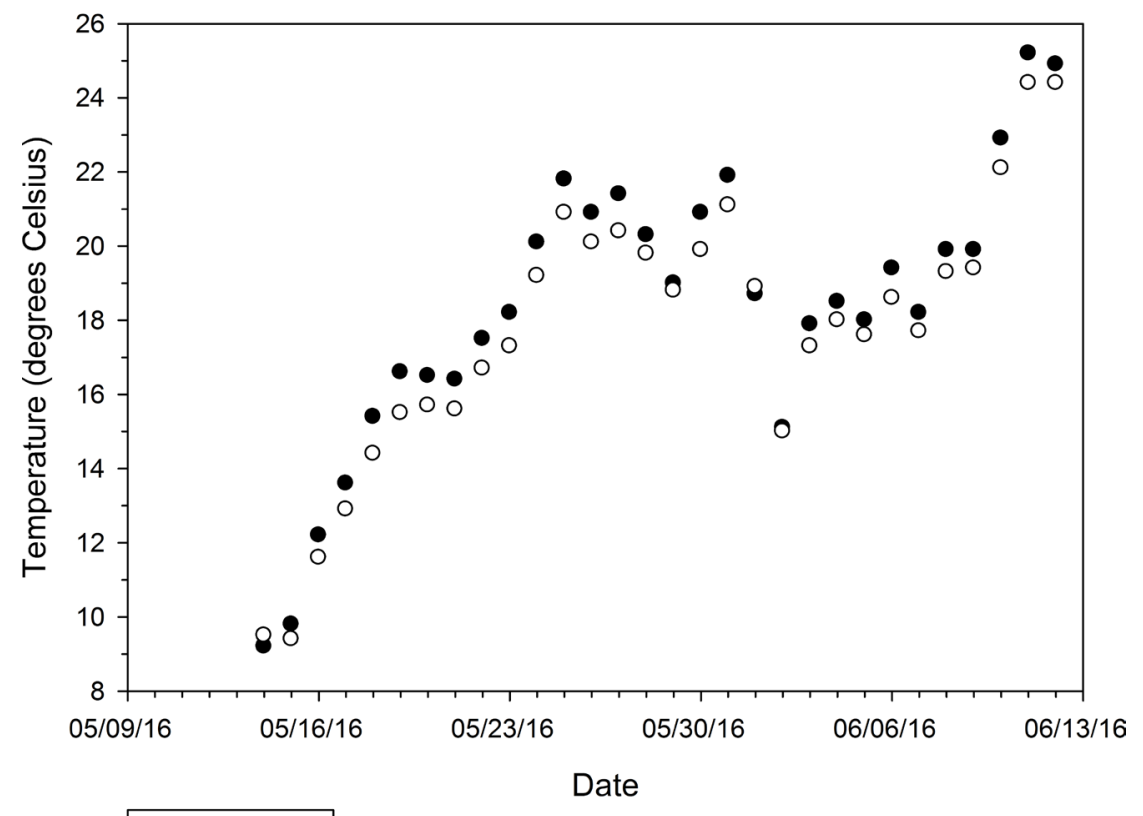

$\begin{array}{ll}- & \text { Lined } \\ \text { - } & \text { Earthen }\end{array}$

Figure 2. Average daily water temperature (degrees Celsius) for one lined and one earthen-substrate pond at Blue Dog State Fish Hatchery, South Dakota between May 14 and June 12, 2016.

Table 4. Mean $( \pm \mathrm{SE})$ concentrations of ammonia-nitrogen $(\mathrm{mg} / \mathrm{L}), \mathrm{pH}$, and dissolved oxygen $(\mathrm{mg} / \mathrm{L})$ for lined and earthen substrate ponds during two periods of the 2016 walleye culture period at Blue Dog State Fish Hatchery, South Dakota. Lined ponds were stocked on May 11 or 12, while earthen ponds were stocked on May 10. Variables were measured seven times at three to seven-day increments with four measurements occurring before and three measurements occurring after May 30.

\begin{tabular}{ccccccc}
\hline \multirow{2}{*}{$\begin{array}{c}\text { Pond } \\
\text { type }\end{array}$} & \multicolumn{3}{c}{ Before May 30 } & \multicolumn{3}{c}{ After May 30 } \\
\cline { 2 - 7 } & Ammonia-N & pH & D. Oxygen* & Ammonia-N & pH & D. Oxygen* \\
\hline Lined & $0.02 \pm 0.01$ & $8.48 \pm 0.03$ & $9.46 \pm 0.39$ & $0.22 \pm 0.04^{\mathrm{y}}$ & $8.17 \pm 0.05$ & $7.95 \pm 0.47^{\mathrm{y}}$ \\
Earthen & $0.01 \pm 0.01$ & $8.47 \pm 0.03$ & $9.92 \pm 0.32$ & $0.01 \pm<0.01^{\mathrm{z}}$ & $8.27 \pm 0.06$ & $9.29 \pm 0.25^{\mathrm{z}}$ \\
\hline
\end{tabular}

${ }^{\star}$ Refers to Dissolved Oxygen; Differing superscripts within a column indicate a significant difference between pond type $(P \leq 0.05)$.

$=1,10, P=0.240$; Table 4). In earthen ponds, $\mathrm{pH}$ remained stable between May 12 and June $10($ F-ratio $=2.001, \mathrm{df}=6,7, P=0.193$; Figure 3$)$. However, $\mathrm{pH}$ changed significantly over that time in lined ponds (F-ratio $=47.656 ; \mathrm{df}=6,7, P$ $<0.000)$. A significant decline began on May 25 and continued through May 31 $(P \leq 0.001)$ followed by a significant increase on June $10(P=0.003)$.

Dissolved oxygen was not significantly different between treatments prior to May 30 (F-ratio $=0.878, \mathrm{df}=1,14, P=0.365$ ), but was significantly lower in lined ponds after May 30 (F-ratio $=6.482, \mathrm{df}=1,10, P=0.029$; Table 4). Both treatments began above $10 \mathrm{mg} / \mathrm{L}$ and significantly changed over time (lined: F-ratio $=111.753, \mathrm{df}=6,7, P<0.000$; earthen: F-ratio $=7.764, \mathrm{df}=6,7, P=$ 


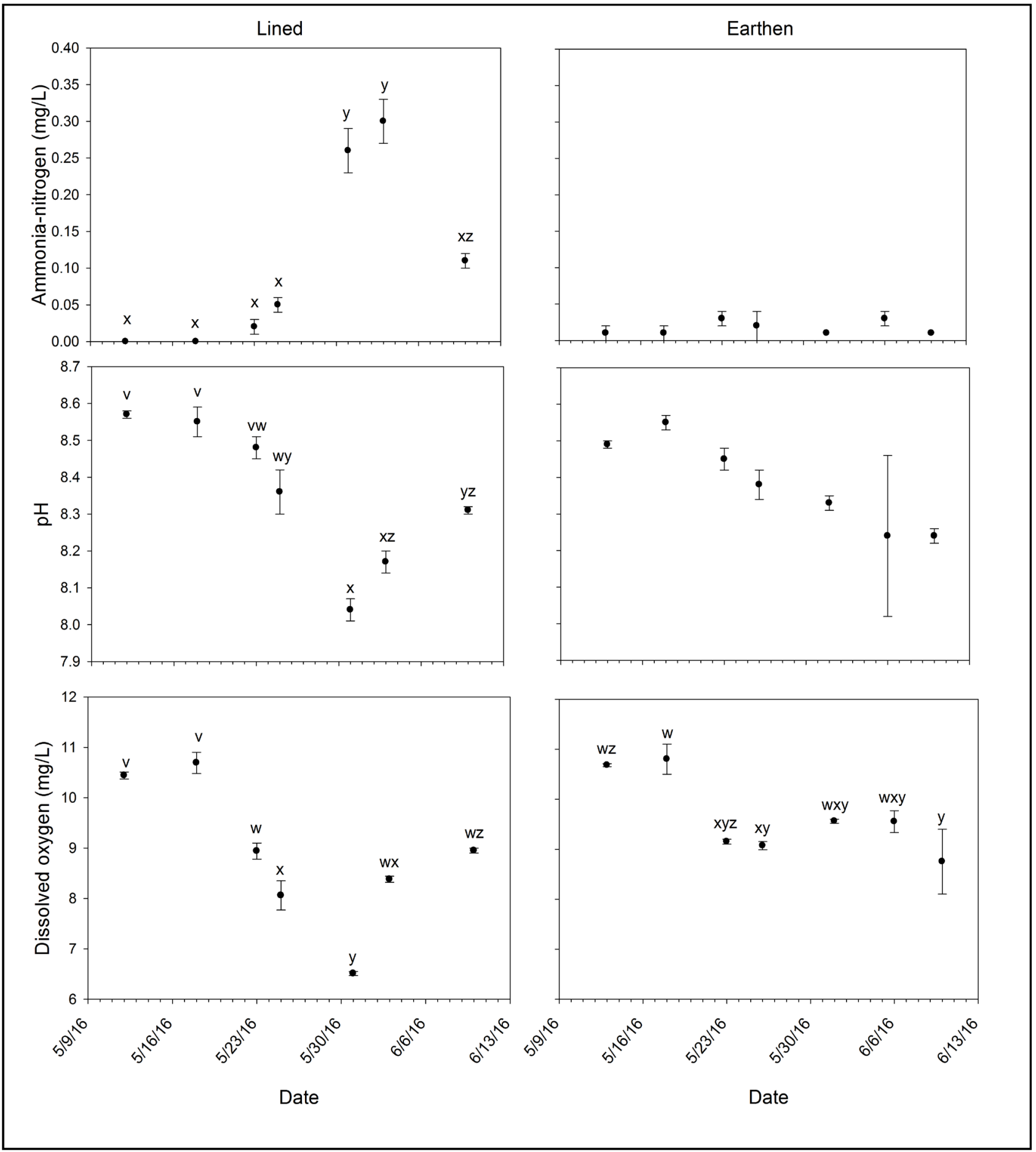

Figure 3. Means $( \pm \mathrm{SE})$ for ammonia-nitrogen $(\mathrm{mg} / \mathrm{L}), \mathrm{pH}$, and dissolved oxygen $(\mathrm{mg} / \mathrm{L})$ concentration over time in lined and earthen substrate ponds used to rear walleye at Blue Dog State Fish Hatchery, South Dakota. Means that do not contain the same letter are significantly different $(P \leq 0.05)$. Figures without letters indicate that no difference was detected $(P>0.05)$. Lined ponds were stocked on May 11 or 12, while earthen ponds were stocked on May 10, 2016.

0.008; Figure 3). In earthen ponds, dissolved oxygen gradually decreased during the interval $(P \leq 0.049)$ with the lowest mean value $(8.8 \mathrm{mg} / \mathrm{L})$ occurring on June 10. In lined ponds, dissolved oxygen concentration decreased abruptly to 6.5 
$\mathrm{mg} / \mathrm{L}(P \leq 0.02)$ through May 31 before increasing on June 3 and $10(P<0.001)$.

\section{Discussion}

Lined ponds enhanced walleye performance measures. Specifically, an increased number of walleyes and yield were produced without reducing individual fish size at harvest compared to earthen ponds. This is noteworthy because walleye size typically decreases as harvest density increases [7]. Moreover, walleyes grew faster during the early and middle stages of the approximate 35-d interval even though a higher stocking density was used. When the same stocking density was used between pond types, yield and fish size at harvest were increased, but the number harvested was not different [1]. Relating the increased growth rates and production with the number of zooplankton and chironomids within walleye digestive tracts was difficult as no statistical differences were detected. The increased walleye density in lined ponds that initially grew faster, potentially indicates that more prey was being consumed during the early part of the trial. Walleyes are known to initially consume copepods and Cladocerans regardless of pond substrate [3] [4] and a spike in zooplankton consumption was noted on June 6 in lined ponds. Larval chironomids also are known to be an important walleye prey in both pond types [4] [8] and their consumption was occurring when the initial growth advantage was measured. While no differences in food habits were clearly identified, the initial increased growth of higher numbers of walleyes provides evidence that an enhanced nutritional food web was available in lined ponds, and this occurred with reduced alfalfa meal use.

Walleye $\delta^{13} \mathrm{C}$ signatures were consistently more negative (i.e., less enriched) in lined ponds. Reduced enrichment of the walleyes (i.e., consumer) reflects prey consumption that has an increased pelagic signature. Pelagic producers exhibit a substantial reduction (e.g., 6\%o) in $\delta^{13} \mathrm{C}$ enrichment compared to benthic producers [13] and little $(<1 \%)$ fractionation occurs when prey is assimilated [20]. While walleye diets were generally similar between pond types throughout the culture interval, the reduced enrichment of walleye on May 31 (2\%o more negative) and at harvest (3.3\% more negative) indicates that the food web (i.e., zooplankton and chironomids) contains a more pelagic signature in lined ponds. At harvest, walleye reflected an increase in carbon enrichment (i.e., more benthic signature) in both pond types likely owing to an increase in larval chironomid consumption as noted in the walleye diet analysis.

Higher ammonia-nitrogen concentrations may have contributed to the increased pelagic signature of the walleyes in lined ponds. Ammonia is readily used by phytoplankton that promote zooplankton growth and reproduction [21] [22]. Inorganic nitrogen is needed in higher concentrations than phosphate (20 to 1) to enhance the phytoplankton that support the zooplankton [6]. The available phytoplankton would also influence the signature of larval chironomids due to potential herbivory [10]. Additional research to include phytoplankton composition and abundances may assist with explaining the increased pelagic signa- 
ture of the food web in lined ponds. Additional nutrient (i.e., nitrate and phosphate) concentrations available to phytoplankton may also prove useful as ammonia concentrations were not different between pond types until after May 30 and substantial food web development and assimilation by the walleye had already occurred.

Water temperature was slightly warmer in lined ponds between May 14 and June 12, which is similar to previous findings [1]. This temperature difference could be accounted for by postponing harvest one day in earthen ponds. In this study, the culture period was actually one day longer in the earthen ponds, but production in lined ponds remained higher suggesting that the available food web is more important than the slight temperature difference in explaining the enhanced walleye performance measures.

Lined ponds exhibited increased variability in the other water chemistry measures, and this occurred with reduced alfalfa meal use. After May 30, lower dissolved oxygen and higher ammonia-nitrogen concentrations combined with an abrupt $\mathrm{pH}$ decrease in lined ponds suggest an increased decomposition rate of the alfalfa meal [5] [16]. Slightly higher water temperatures in lined ponds would contribute to a higher decomposition rate of the fertilizer [16]. Additionally, these water chemistry patterns in lined ponds could be explained by a reduction in photosynthesis where zooplankton have overgrazed the edible phytoplankton [23] [24]. The dynamic patterns in water chemistry that occurred with reduced alfalfa meal use suggest that organic fertilizer is used more efficiently in lined ponds to promote increased walleye production. Emphasizing fertilizer strategies that decrease dissolved oxygen $(\approx 6.5 \mathrm{mg} / \mathrm{L})$ and increase ammonia-nitrogen $(\approx 0.3 \mathrm{mg} / \mathrm{L})$ concentrations, while maintaining $\mathrm{pH}$ between 8.0 and 8.2 during the second half of the rearing interval may provide improved production in earthen ponds at this facility.

Previously no meaningful biological differences in water chemistry were identified between lined and earthen-substrate ponds used in walleye production [1]. In the current study, the use of alfalfa meal (instead of chopped hay) emphasized water chemistry differences between substrate types and provides direction for improving production in earthen substrate ponds at this facility. Future evaluation in earthen substrate ponds should include increased rates of alfalfa meal supplemented with inorganic nitrogen (28-0-0) in an effort to promote similar water chemistry measures as observed in the lined pond treatment of this study.

\section{Acknowledgements}

We would like to thank the staff at Blue Dog Hatchery including J. Broughton, R. Smidt, R. Rasmus, N. Pool, C. Haabala, C. Jung and J. Anderson for their efforts and involvement with the collection and publication of these data. Thanks to Dr. S. Chipps for his assistance in preparing samples for stable isotope analysis. Partial funding was provided by the Federal Aid to Sportfish Restoration Project F-41-D-14. 


\section{Conflicts of Interest}

The authors declare no conflicts of interest regarding the publication of this paper.

\section{References}

[1] Ward, M.J., Uphoff, C., Stane, J., Borah, B., Henry, A., Billings, J. and Johnson, B. (2011) Walleye Fingerling Culture in Earthen and Ethylene Propylene Diene Monomer-Lined Ponds. North American Journal of Aquaculture, 73, 1-7.

[2] Ward, M.J., Stane, J., Schrock, G. and Funk, C. (2012) Effect of Stocking Density on Walleye Performance in Ponds Lined with Ethylene Propylene Diene Monomer. North American Journal of Aquaculture, 74, 127-131. https://doi.org/10.1080/15222055.2012.672371

[3] Summerfelt, R.C., Clouse, C.P. and Harding, L.M. (1993) Pond Production of Fingerling Walleye, Stizostedion vitreum, in the Northern Great Plains. Journal of Applied Aquaculture, 2, 33-58. https://doi.org/10.1300/J028v02n03_03

[4] Rogge, M.L., Moore, A.A. and Morris, J.E. (2003) Organic and Mixed Organic-Inorganic Fertilization of Plastic-Lined Ponds for Fingerling Walleye Culture. North American Journal of Aquaculture, 65, 179-190. https://doi.org/10.1577/C02-022

[5] Summerfelt, R.C., Johnson, J.A. and Clouse, C.P. (2011) Culture of Walleye, Sauger, and Hybrid Walleye. In: Barton, B.A., Ed., Biology, Management, and Culture of Walleye and Sauger, American Fisheries Society, Bethesda, 451-570. https://doi.org/10.47886/9781934874226.ch13

[6] Helal, H.A. (1990) Nitrogen: Phosphorus Ratio and Trophic Dynamics in Fish-Hatchery Ponds. PhD Dissertation, the Ohio State University, Columbus.

[7] Culver, D.A., Madon, S.P. and Qin, J. (1993) Percid Pond Production Techniques: Timing, Enrichment, and Stocking Density Manipulation. Journal of Applied Aquaculture, 2, 9-31. https://doi.org/10.1300/J028v02n03_02

[8] Fox, M.G., Keast, J.A. and Swainson, R.J. (1989) The Effect of Fertilization Regime on Juvenile Walleye Growth and Prey Utilization in Rearing Ponds. Environmental Biology of Fishes, 26, 129-142. https://doi.org/10.1007/BF00001029 https://link.springer.com/article/10.1007/BF00001029

[9] Barkoh, A. and Rabeni, C.F. (1990) Biodegradeability and Nutritional Value to Zooplankton of Selected Organic Fertilizers. Progressive Fish-Culturist, 52, 19-25. https://doi.org/10.1577/1548-8640(1990)052<0019:BANVTZ>2.3.CO;2

[10] Hilsenhoff, W.L. (2001) Diversity and Classification of Insects and Collembola. In: Thorp, J.H. and Covich, A.P., Eds., Ecology and Classification of North American Freshwater Invertebrates, Second Edition, Academic Press, San Diego, 661-732.

[11] Hartleb, C.F., Johnson, J.A. and Held, J.A. (2012) Walleye and Yellow Perch Pond Fertilization. In: Mischke, C.C., Ed., Aquaculture Pond Fertilization: Impacts of Nutrient Input on Production, Wiley-Blackwell, Oxford. 147-161. https://doi.org/10.1002/9781118329443.ch11

[12] Harding, L.M. and Summerfelt, R.C. (1993) Effects of Fertilization and of Fry Stocking Density on Pond Production of Fingerling Walleye, Stizostedion vitreum. Journal of Applied Aquaculture, 2, 59-79. https://doi.org/10.1300/J028v02n03_04

[13] France, R.L. (1995) Carbon-13 Enrichment in Benthic Compared to Planktonic Algae: Foodweb Implications. Marine Ecology Progress Series, 124, 307-312. https://www.int-res.com/articles/meps/124/m124p307.pdf https://doi.org/10.3354/meps124307 
[14] Qin, J. and Culver, D.A. (1992) The Survival and Growth of Larval Walleye, Stizostedion vitreum, and Trophic Dynamics in Fertilized Ponds. Aquaculture, 108, 257-276. https://doi.org/10.1016/0044-8486(92)90111-W

[15] Rogge, M.L., Moore, A.A., Clouse, C.P. and Morris, J.E. (2002) Initial Observations of Plastic Lined Ponds for Fingerling Walleye Production. World Aquaculture, 33, 59-61. https://lib.dr.iastate.edu/cgi/viewcontent.cgi?article=1004\&context=aecl_pubs

[16] Boyd, C.E. and Tucker, C.S. (2014) Handbook for Aquaculture Water Quality. Craftmaster Printers, Inc., Auburn.

[17] Bergerhouse, D.L. (1993) Lethal Effects of Elevated pH and Ammonia on Early Life Stages of Hybrid Striped Bass. Journal of Applied Aquaculture, 2, 81-100. https://doi.org/10.1300/J028v02n03_05

[18] Stueven, E.H. and Bren, R. (1999) Phase 1 Watershed Assessment Final Report, Blue Dog Lake, Day County, South Dakota. South Dakota Department of Environment and Natural Resources, Pierre.

[19] Sokal, R.R. and Rohlf, F.J. (1995) Biometry: The Principles and Practices of Statistics in Biological Research. 3rd Edition, W.H. Freeman and Company, New York.

[20] Peterson, B.J. and Fry, B. (1987) Stable Isotopes in Ecosystem Studies. Annual Review of Ecology and Systematics, 18, 293-320. https://doi.org/10.1146/annurev.es.18.110187.001453

[21] Barcia, J., Kling, H. and Gibson, J. (1980) Experimental Manipulation of Algal Bloom Composition by Nitrogen Addition. Canadian Journal of Fisheries and Aquatic Sciences, 37, 1175-1183. https://doi.org/10.1139/f80-150

[22] Bednarska, A., Pietrzak, B. and Pijanowska, J. (2014) Effect of Poor Manageability and Low Nutritional Value of Cyanobacteria on Daphnia magna Life History Performance. Journal of Plankton Research, 36, 838-847. https://doi.org/10.1093/plankt/fbu009

[23] Qin, J. and Culver, D.A. (1995) Effect of Young-of-the-Year Walleye (Percidae: Stizostedion vitreum) on Plankton Dynamics and Water Quality in Ponds. Hydrobiologia, 297, 217-227. https://doi.org/10.1007/BF00019286

[24] Culver, D.A. (1996) Fertilization Procedures for Pond Culture of Walleye and Saugeye. In: Summerfelt, R.C., Ed., Walleye Culture Manual, NCRAC Culture Series 101, North Central Regional Aquaculture Center Publications Office, Iowa State University, Ames, 115-122. 